$$
\begin{aligned}
& \text { インターフェロンが原発巣拉よび下大静脈内 } \\
& \text { 腫瘍血栓に奏効した腎細胞癌の } 1 \text { 例 } \\
& \text { 大阪府立成人病センター泌尿器科（部長：古武敏彦博士） } \\
& \text { 永野哲郎 前田修細木 茂 } \\
& \text { 木内 利明 黒田 昌男 三木 恒治 } \\
& \text { 宇佐美道之 中村麻瑳男 古武 敏彦 } \\
& \text { 同 循環動態科 (部長：小林 亨) } \\
& \text { 小林烹 }
\end{aligned}
$$

\title{
SUCCESSFUL INTERFERON THERAPY OF RENAL CELL CARCINOMA WITH TUMOR THROMBUS EXTENDING INTO THE INFERIOR VENA CAVA -A CASE REPORT-
}

Tetsuo Nagano, Osamu Maeda, Shigeru Saiki, Toshiaki Kinouchi, Masao Kuroda, Tsuneharu Miki, Michiyuki Usami, Masao Nakamura,

Toshihiko Kotake and Tohru Kobayashi*

Department of Urology and Department of Cardiovascular Surgery*, The Center for Adult Diseases, Osaka

It is a fact that there are few effective drugs available except for interferon for that treatment of renal cell carcinoma, and the efficacy rate of interferon is less than $10 \%$ even if multiple drug regimens are included. We have experienced a case of renal cell carcinoma in whom interferon therapy was successful in reducing the primary lesion and tumor thrombus extending into the inferior vena cava.

A 57-year-old man was admitted to our department with a complaint of macroscopic hematuria. Computed tomography and magnetic resonance imaging revealed a right renal tumor and the tumor thrombus. Because of the past history of his myocardial infarction, a radical operation was considered risky. So we started interferon therapy. Four months after the start of interferon therapy, the primary lesion and the tumor thrombus markedly reduced in their size, and the clinical response was evaluated as partial response by response criteria for urological cancer treatment. Therefore, radical nephrectomy and tumor thrombectomy were performed with extracorporeal circulation.

Histopathologically, necrosis and lymphocyte infiltration into the cancer cell focus were seen, and these immunologic reactions were considered at the affection of interferon. In some case, interferon therapy is a useful and safe in the treatment of the primary lesion of renal cell carcinoma, and further investigation must be studied.

Key words: interferon, renal cell carcinoma, tumor thrombus extending into the inferior vena cava

要旨: 症例は57歳の男性で, 無症候性肉眼的血尿を主訴に来院した。諸検查にて右腎静脈から肝静脈流 入部に抢よぶ下大静脈内腫瘍血栓を伴ら右腎細胞癌 (T3N0M0V2) と診断した。 心筋梗塞の既往及び狭 心症を合併していたため経皮的冠動脈形成術を施行後, シメチジン併用にて天然型インターフェロン $\alpha$ を投与した. IFN を計 3 億 6 千万単位投与した 4 カ月後での CT にて，右腎は著明に縮小し CT 上明か な腫瘍は認めず，また腫瘍血栓は腎静脈分岐部より約 $5 \mathrm{~cm}$ 頭側をで縮小し血栓に対する縮小率は $70 \%$ で, 臨床的治療効果総合判定は PR であった。体外循環下に根治的右腎摘除術及び下大静脈壁部分切除を 伴う腫漡血栓摘出術を施行した。摘出標本は右腎, 腫瘍血栓を併せて $10 \times 10 \times 12 \mathrm{~cm}$ 大, 重量 $180 \mathrm{~g}$. 病理 組織学的には原発巣, 腫瘍血栓ともに clear cell subtype, grade $2>$ grade 1であった。腎下極, 腫場血 栓とも広範囲に出血壊死を認め，炎症細胞浸潤が著明であった。腎癌の組織学的治療効果判定基準では 腎は Grade 1b, 腫瘍血栓は Grade 3であり，IFN の効果と思われた。腎摘除後13力月後の現在転移，再 
発の徴候もなく健在である. IFN が原発巣に対し PR 以上の効果を示したのは, 我々の調べ得た範囲で は，本邦でこれまで 3 例に過ぎず，かついずれも腎は摘除されておらず病理組織学的検索はなされてい ない，本例の経験から原発巣に対するIFN の効果も今後検討の余地があると思われた。 キーワード：インターフェロン, 腎細胞癌, 下大静脈内腫瘍血栓

\section{緒 言}

最近, インターフェロン (以下 IFN と略す)の腎細 胞癌に対する有効例が報告されているが，その多くは 肺転移巣に対する有効例である。 今回我々は，IFN が 原発巣および下大静脈内腫瘍血栓に奏効した腎細胞癌 の 1 例を経験したので，若干の文献的考察を加兄報告 する.

\section{症例}

患者：57歳，男性.

主訴：無症候性肉眼的血尿。

既往歴：1983年心竻梗塞.

家族歴：特記すべさことなし。

現病歷：1990年 6 月, 無症候性肉眼的血尿のため当 科を受診。膀脱鏡にて右尿管口よりの血尿，DIP にて 右下腎杯の陰影欠損，エコーにて右腎に腫瘍を認めた ため 6 月 25 日入院となった.

入院時現症：身長 $165 \mathrm{~cm}$ ，体重 $50 \mathrm{~kg}$. 身体所見に異 常を認めなかった。

入院時検查成績：血液一般, 生化学的検査では, 赤 沈元進（1 時間值 $18 \mathrm{~mm}, 2$ 時間値 $42 \mathrm{~mm}$ ), 軽度の貧 血 ( $\mathrm{Hb} 11.3 \mathrm{~g} / \mathrm{dl}$ ) 認める以外異常はなかった，尿沈 椬にて顥微鏡的血尿（RBC 15～20/hpf）を認めた。尿 細胞診は陰性であった。心電図では前壁の陳旧性梗塞 を認めた。

画像診断：CT，MRIにて右腎下極に直径約 $5 \mathrm{~cm}$ の 腫瘍および右腎静脈から肝静脈流入部におよぶ下大静 脈内腫瘍血栓を認めた(図 1 上)，腹部エューも同様の 所見であった。胸部 X 線，骨シンチグラムには異常所 見を認めなかった。

以上より下大静脈内腫瘍血栓を伴った右腎細胞癌 （T3N0M0V2）と診断した.

治療経過：根治手術を計画していたが，術前評価中 にも狭心発作があり, 冠動脈造影の結果, 左前下行枝 の完全閉塞および回旋枝の $90 \%$ 狭窄を認めたので，回 旋枝に対し経皮的冠動脈形成術（PTCA）を施行した。 このため手術を延期し，PTCA 後30日目よりシメチジ ン一日 $800 \mathrm{mg}$ 経口投与下に天然型 IFN $\alpha 500$ 万単位を 連日筋注したが，投与開始後 1 カ月は腫瘍はむしろ一 時的に増大した。投与58日目退院し，外来にて IFN 500 万単位を週 3 回筋注していたが, 投与 4 カ月後, 計 3 億 6 千万単位投与した時点の CT で腫瘍の縮小を認め たため，1991年 1 月 8 日腎摘除術目的で再入院となっ た。 IFN の副作用としては，発熱，全身倦志感，白血
図 1 上：インターフェロン投与前の腹部 CT 像：右 腎腫瘍および下大静脈内腫瘍血栓を認める。下：イ ンターフェロン投与開始後 4 カ月の腹部 $\mathrm{CT}$ 像：右 腎は正常大以下に縮小し,腫愓は画像上明かでない。 腫瘍血栓も70\%縮小した。
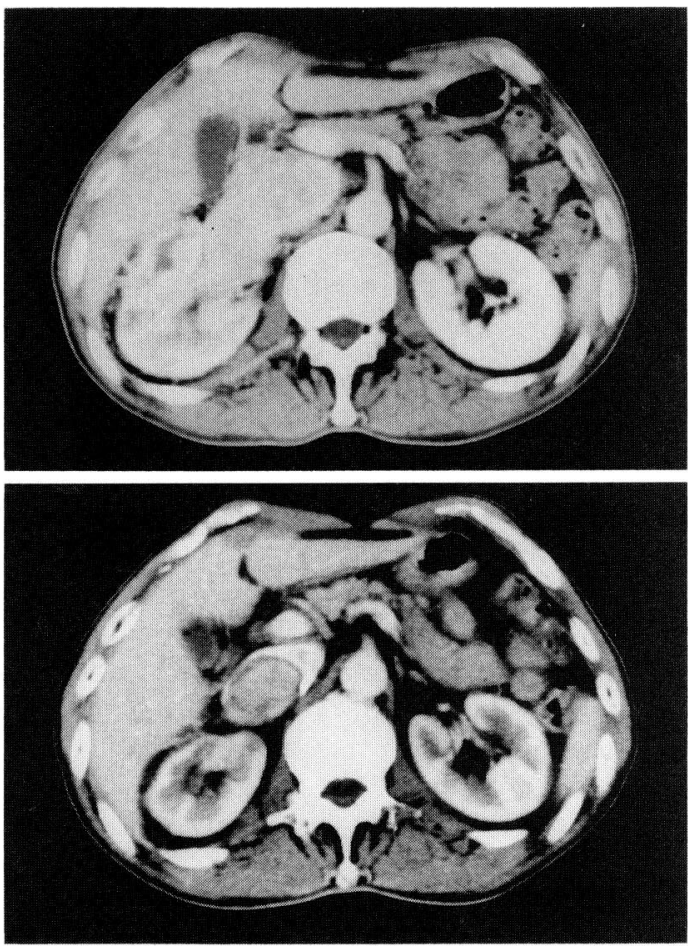

球減少を認めたが，いずれも軽度で投与継続に支障は なかった。

再入院時， IFN 投与 6 カ月目の CT では，右腎は正 常大以下とさらに著明に縮小し面積縮小率 $63 \%$ で, CT 上明らかな腫湯は認めなかった。腫瘍血栓も肝静脈流 入部にまでおよんでいたものが腎静脈分岐部より頭側 約 $5 \mathrm{~cm}$ までに縮小し，面積縮小率は70\%であった（図 1下)。これらより, 腎癌の非観血的治療効果判定基

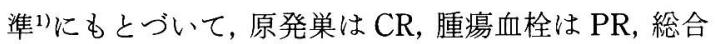
で PR と判定した。入院後さらに, 完全閉塞していた左 前下行枝に対しても PTCA 試みたが不成功であっ た。しかし循環動態学上手術可能と判断し，1月21日 体外循環下に根治的腎摘除術および腫瘍血检摘出術を 施行した. 
手術所見：腹部正中切開に胸骨縦切開を追加し, 右 心耳打よび右大腿静脈より脱血, 上行大動脈より送血 し人工心肺を作動した。 下大静脈を心的合流直前お よび腎静脈分岐部より末梢で遮断し，下大静脈を切開 した。肝静脈, 左腎静脈, 腰静脈よりの出血を吸引し つつ腫瘍血栓および右腎を一塊として摘出したが, 右 腎静脈分岐部付近の腫瘍血栓は下大静脈々癒着して拧 り，下大静脈壁を合併切除した。迅速病理検査にて断 端陰性であることを確認した後, 約 $3 \times 7 \mathrm{~cm}$ の欠損を 自己心膜パッチにて閉鎖した。体外循環時間は 43 分で あった。

病理組織学的所見：摘出標本は, 原発巣および腫瘍 血栓を併せて $10 \mathrm{~cm} \times 10 \mathrm{~cm} \times 12 \mathrm{~cm}$ 大, 重量 $180 \mathrm{~g}$ で あった。原発巣の腫瘍は出血, 壊死が汪とんどで肉眼 的には明かでなく, 腫瘍血栓は右腎下極より腎静脈を 介して腎静脈分岐部より約 $5 \mathrm{~cm}$ 頭側の下大静脈内本 で連続性に進展していた。

組織学的には原発巣, 腫瘍血栓とも renal cell carcinoma, clear cell subtype, grade $2>$ grade 1であ り, 広範囲に出血壊死, 炎症細胞浸潤を認めた。原発 巣では viable cell は腫瘍全割面の約 $50 \%$ に散在し（図 2), 腫瘍血栓においては viable cell は認めず, 腎癌の 組織学的治療効果判定基準 ${ }^{1}$ では原発巣は Grade 1b,

腫瘍血栓は Grade 3であった。

術後経過: 術後経過は良好で術後49日目に略治退院 となった。術後14日目より補助療法として IFN 500 万 単位を週 3 回, 計25回投与し IFN 療法を終了したが, 術後13力月を経過した現在, 転移, 再発の兆候もなく, Performance status 0 と健在である.

\section{考察}

腎細胞癌が下大静脈内に腫瘍血栓を伴う頻度は 5 $\sim 10 \%{ }^{23)}$ とされている. 以前はこのような症例は予後 不良とされていたが, Skinner ら²が遠隔転移のない症 例に対し, 原発巣之腫瘍血栓の同時摘出を行って良好 な結果を報告して以来, 本邦でも積極的に腹瘍血栓摘 出術が行われるよらになった。当科では, 腫瘍血栓が 肝静脈流入部までおよぶ場合は, 体外循環の適応とし ている. 本症例も体外循環下での根治手術を計画した が，虚血性心疾患の合併のためまずPTCAを行い，そ の間 IFN を投与することにした。
図 2 摘出腎の病理組織像：広範囲に炎症細胞浸潤と 壊死を認める。（HE染色, $\times 20)$

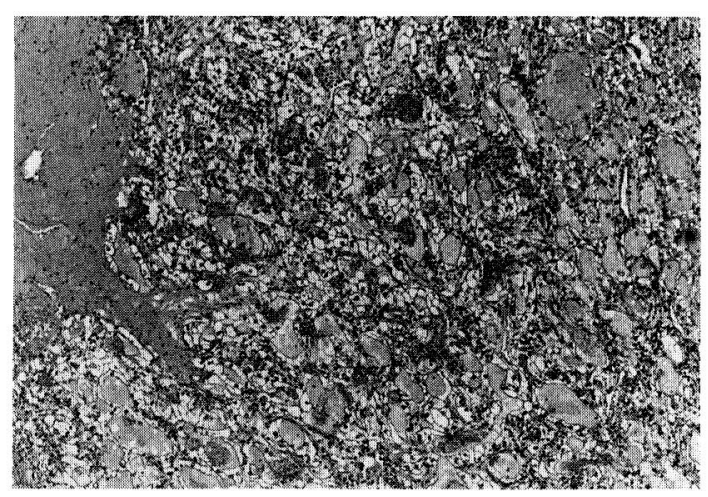

IFN の腎細胞癌に対する有効率は諸家の報告によ ると $6 \%$ 37\%, 平均して $20 \%$ 前後 ${ }^{4) ~ 7) て ゙ あ る . ~ し か ~}$ し, 病巣部位別にみると, 肺に対しては $20 \%$ 前後の有

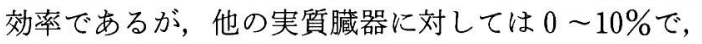
特に原発巣に詨する有効率はUmeda ら ${ }^{8)}$ の報告をは じめ $0 \%$ \%汇とんどである。たと原発巣を有する症 例で効果を認めても転移巣に対する有効例が大半であ り, 原発巣自体に対してPR 以上の効果が得られたも のは, 我々の調べ得た限りでは, 腎動脈塞栓術, 化学 療法等々併用されたものを含めても 3 例9 位に過ぎ ない(表 1 ). さらに自験例以外はいずれも原発巣は摘 除されて抢らず，病理組織学的検討が加兄られていな い.

また, 下大静脈内腫瘍血栓に対する IFN の効果は, 自験例が加藤ら ${ }^{12)}$ の報告に次いで 2 例目の有効例と なっている.

IFN の効果判定は, その対象のほとんどが転移巣で あるため画像診断によることが多く, 組織学的検索は ほとんどなされていない.転移巣の検討では, 山内ら ${ }^{13)}$ が14例の剖検例に拀いて，転移巣に効果がみられた症 例は原発巣が clear cell subtype で grade $3 の も の に$ 効果は限られていたことから, 核異型の少ないものに は効果がないと考えられると述べている。これに対し て里見ら ${ }^{4)}$ は腎摘除術がなされた19例の転移巣を検討

表 1 本邦に括けるインターフェロンの原発巣有効例

\begin{tabular}{c|c|c|c|c|c|l|l}
\hline 報告者 & 性 & 年齢 & IFN の種類 & $\begin{array}{c}\text { 総投与量 } \\
\left(\times 10^{6} \text { IU }\right)\end{array}$ & 効果 & 併用療法 & \multicolumn{1}{|c}{$\begin{array}{c}\text { 転 帰 } \\
(\text { 月 })\end{array}$} \\
\hline 高橋ら & 女 & 51 & IFN $\gamma$ & 1480 & PR & 化学療法 & 死亡(11) \\
浅川ら & 男 & 70 & IFN $\alpha$ & 213 & PR & 塞栓術 & 生存(4) \\
高橋ら & 男 & 76 & IFN $\alpha$ & 不明 & PR & & 死亡(11) \\
自験例 & 男 & 57 & IFN $\alpha$ & 485 & PR & シメチジン & 生存(13) \\
\hline
\end{tabular}


し，原発巣の grade の低いものに有効例が多いとして いる.我々は摘出標本を $7 \mathrm{~mm}$ 間隔の連続平行割断にて 検討した。 その結果, 原発巣, 腫瘍血栓ともに clear cell subtype, grade $2>$ grade 1であった。病理組織学的効 果判定は腎癌の組織学的治療効果判定基準 ${ }^{1}$ によれ ば, 原発巣は Grade 1b, 腫瘍血栓には viable な腫瘍細 胞を認めず，大半は壊死または線維化しており Grade 3 と判定される. IFN 投与前の cell type, grade が不明 なので, どのような細胞にどのような機序で IFN が効 果を発現したか明らかにするのは不可能であるが，リ ンパ球を中心とした炎症細胞浸潤が広範囲にみられた ことより，直接抗腫瘍効果だけでなく，NK 細胞活性 化, 細胞障害性 T 細胞の活性化などの免疫学的機序を 含む Biological response modifiers (BRM) としての 作用が関与している可能性が示唆された。

IFN の効果発現時期については，丸茂ら ${ }^{14)}$ は肺転移 单に対してではあるが，MR 以上の効果発現まで 11〜14週要するため 12 週間以上の投与が必要であると 報告し，その理由としてIFN が免度系を介して作用す ること，および直接抗腫瘍効果が殺細胞作用ではなく 増殖抑制作用であると考えられるためとしている。 我々の症例も PR となるまでに16週を要し，病理組織 学的所見からも免疫系の関与が示唆され, 丸茂らの報 告と一致すると思われる。

当科では, サプレッサーT 細胞を賦活化するヒスタ ミン受容体の blockerであるシメチジンを併用し IFN 療法を行い, IFN 単独投与より高い奏効率を得て いる15)。しかし原発巣に対してはこれまで 4 例に併用 投与しているが, 有効は本症例のみであり, 残りの 3 例は無効で 1 年以内に癌死している.

まれではあるが IFN は自験例のごとく原発巣にも 有効な場合があり，今後さらに検討する必要があると 思われる。

IFN が，原発巣および下大結脈内腫瘍血栓に奏効し た腎細胞癌の 1 例を若干の文献的考察を加え報告し た。

本論文の要旨は, 第135回日本泌尿器科学会関西地方会で 発表した。

な技本報告は厚生省がん研究助成金(課題番号2-21)の補 助を受けた。

\section{文献}

1) 日本泌尿器科学会, 日本病理学会 (編)：腎癌の治 療効果判定基準. 日泌尿会誌, 83, 449-452, 1992.

2) Skinner, D.G., Pfister, R.F. and Colvin, R.: Extensin of renal cell carcinoma into the vena cava: The rationale for aggresive surgical management. J. Urol., 107, 711-716, 1972.

3）增田富士男, 佐々木忠正, 小路 良, 陳 瑞昌, 町
田豊平：腎細胞癌の下大静脈内腫瘍栓塞。日泌尿 会誌, 70, 1061-1071，1979.

4）里見佳昭, 仙賀 裕, 福田百邦, 河合恒雄：腎細胞 癌の化学療法. 第 4 報. インターフェロン療法. 日 泌尿会誌, 75, 909-916, 1984.

5）小野佳成，大島伸一，藤田民夫，浅野春好，名出頼 男, 鈴木和雄, 阿兽佳郎, 有吉 寛, 福島雅典, 太 田和雄：ヒトリンパ芽球インターフェロン (HLBI) の腎細胞癌への効果. 日癌治, 18, 962-968, 1983.

6）本間之夫, 䇾和田滋, 東原英二, 阿曽佳郎：腎細胞 癌に対する $\alpha$-インターフェロンの治療経験. 日癌 治, 26, 755-759, 1991.

7) Horoszewicz, J.S. and Murphy, G.P.: An assessment of the current use of human interferons in therapy of urological cancers. J. Urol., 142, 1173-1180, 1989.

8) Umeda, T. and Nijima, T.; Phase II study of alpha interferon on renal cell carcinoma : Summary of three collaborative trials. Cancer, 58 , $1231-1235,1986$.

9）高橋義人, 堀江正宣, 磯貝和俊, 竹内敏視, 栗山 学, 河田幸道: 遺伝子組換光 Interferon が奏功し た腎細胞癌の 1 例. Biotherapy, 2, 613-617, 1988.

10）浅川正純, 前川たかし, 梅田 優, 坂本 亘, 千住 将明, 井関達男, 仲谷達也, 田中 寛, 堀井明範, 山本啓介, 川村正喜, 森川洋二, 山口哲男, 柏原 昇, 川喜多順二, 西島高明, 松村俊宏, 大山武司, 西尾正一, 早原信行, 过田正昭, 和田誠次, 安本亮 二, 岸本武利, 前川正信：進行腎細胞癌に対する七 トリンパ芽球由来インターフェロン (HLBI) 単独 療法と抗癌剂との併用療法の比較. 泌尿紀要, 35, $1451-1455,1989$.

11）高橋 遼, 立花康人, 佐藤修二, 腰山達美, 大城 忠, 犬童伸行, 内山 清, 畑中恒人：インターフェ ロンが奏効した腎癌の 1 例. 道南医学会誌, 25, $151-153,1990$.

12）加藤一哉, 小野寺一彦, 草野満夫, 鈴木康之, 西田 靖仙, 水戸廸郎, 村岡俊二：インターフェロンの持 続動注により下大静脈腫瘍血栓の著明な縮小をみ た腎癌の 1 例。日臨外医会誌，50，2257-2263， 1989.

13）山内民男，川村寿一，吉田 修，福山拓夫，小倉啓 司, 中川清秀：腎癌に対する $\alpha$ 型インターフェロ ンの抗腫瘍効果検討：病理剖検例を中心に。泌尿 紀要, 31，1539-1552，1985.

14）丸茂 健, 早川正道, 村井 勝, 田崎 寛: 進行腎 細胞癌に対するヒト $\alpha$ 型インターフェロンの抗 腫瘍効果とその免疫学的検討. 日泌尿会誌, 76, 965-973，1985.

15）木内利明, 細木 茂, 黒田昌男, 三木恒治, 清原久 和, 宇佐美道之, 古武敏彦：遠隔転移を有する腎細 胞癌に対する Human Lymphoblastoid AlphaInterferon 療法. Biotherapy, 2, 196-199, 1988. (1992年10月 20 日受理) 